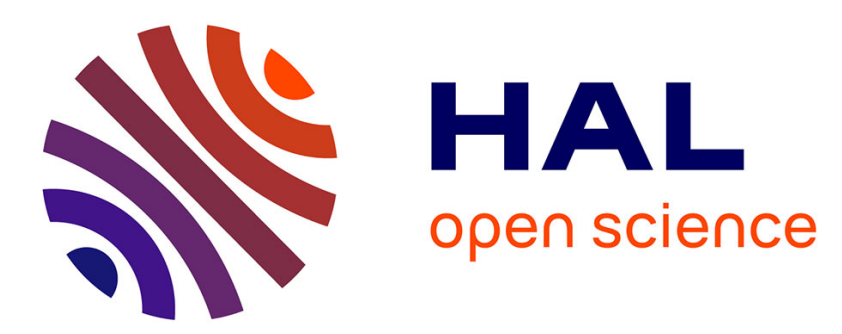

\title{
Origin of the nitrogen assimilated by soil fauna living in decomposing beech litter
}

\author{
Laurent Caner, Bernhard Zeller, E. Dambrine, Jean-François Ponge, M. \\ Chauvat, Curmi Llanque
}

\section{- To cite this version: \\ Laurent Caner, Bernhard Zeller, E. Dambrine, Jean-François Ponge, M. Chauvat, et al.. Origin of the nitrogen assimilated by soil fauna living in decomposing beech litter. Soil Biology and Biochemistry, 2004, 36, pp.1861-1872. hal-00258686}

\section{HAL Id: hal-00258686 \\ https://hal.science/hal-00258686}

Submitted on 24 Feb 2008

HAL is a multi-disciplinary open access archive for the deposit and dissemination of scientific research documents, whether they are published or not. The documents may come from teaching and research institutions in France or abroad, or from public or private research centers.
L'archive ouverte pluridisciplinaire HAL, est destinée au dépôt et à la diffusion de documents scientifiques de niveau recherche, publiés ou non, émanant des établissements d'enseignement et de recherche français ou étrangers, des laboratoires publics ou privés. 


\title{
Origin of the nitrogen assimilated by soil fauna living in decomposing beech litter
}

\author{
Laurent CANER, Bernd ZELLER, Etienne DAMBRINE, \\ Jean-François PONGE, Matthieu CHAUVAT and Curmi LLANQUE
}
Accepted Version: Soil Biology and Biochemistry, 2004, 36, 1861-1872

Adresses :

Caner Laurent*, Zeller Bernd, Dambrine Etienne, Llanque Curmi

INRA Centre de Nancy

Biogéochimie des Ecosystèmes Forestiers

54280 Seichamps (France)

Ponge Jean-François

Muséum National d'Histoire Naturelle

CNRS UMR 8571

91800 Brunoy (France)

\section{Chauvat Matthieu}

Departement of Animal Ecology

Justus Liebig University

35392 Giessen (Germany)

* Address for correspondence

CANER Laurent

Université de POITIERS

FRE CNRS 3114 HydrASA

40, avenue du Recteur Pineau

86022 POITIERS Cedex France

Mail: laurent.caner@univ-poitiers.fr 


\section{Abstract}

We investigated the nitrogen source for main taxa of soil fauna in two beech forests of contrasted humus type using ${ }^{15} \mathrm{~N}$-labelled beech litter and ${ }^{15} \mathrm{~N}$ analysis of soil fauna. ${ }^{15} \mathrm{~N}$ labelled beech litter was deposited on the topsoil in December 2000 in four stands of different ages at Leinefelde (Germany) with mull humus and in one mature stand at Sorø (Denmark) with moder humus. The fate of the tracer isotope was measured in litter and soil, as well as in the soil fauna, and for each taxa, we calculated the proportion of $\mathrm{N}$ in the animal derived from the labelled substrate. Of the original $\mathrm{N}$ contained in the litter, $20 \%$ to $41 \%$ was lost after 9 months at Leinefelde, and only $10 \%$ at Sorø. This loss was counterbalanced by the incorporation of $24 \%$ to $31 \%$ external $\mathrm{N}$ at Leinefelde, and $31 \%$ at Sorø, partly originating from fungal colonisation of the added litter. The proportion of $\mathrm{N}$ assimilated from the labelled litter by the different soil animals varied in relation to their mobility and feeding preferences. Large and mobile soil animals, especially predators, derived on average less ${ }^{15} \mathrm{~N}$ because they were also able to feed outside the labelled litter boxes. Detritivores assimilated at most $15 \%$ of their nitrogen content at Leinefelde and $11 \%$ at Sorø from the decomposing labelled litter. The most labelled taxa at Leinefelde were small fungivorous and coprophagous species, mainly isotomid Collembola such as Isotomiella and Folsomia. At Sorø, best labelled taxa were saprophagous species such as Enchytraeidae, Glomeridae and Phthiracaroidea. These low rates of ${ }^{15} \mathrm{~N}$ assimilation indicate that fresh litter is not directly the main $\mathrm{N}$ source for soil animals. The results obtained suggest that soil fauna fed preferentially upon microorganisms colonising the litter at Leinefelde (mull) and from litter itself at Sorø (moder).

Key words: ${ }^{15} \mathrm{~N}$ tracing, litter, soil fauna, detritivores, predators

\section{Introduction}

Food selection by soil fauna is generally investigated by morphological evidence of tissue degradation and gut content observations in the field and in chamber experiments (Whittaker, 1981; Behan Pelletier and Hill, 1983; Verhoef et al., 1988; Saur and Ponge, 1988; Ponge, 1991a; Klironomos et al., 1992), as well as by choice experiments (Visser and Whittaker, 1977; Shaw, 1988; Stöckli, 1990; Hendriksen, 1990). These investigations, although long and difficult, provide most reliable indications about the different ingested material. However, they do not imply that nutrients $(\mathrm{C}, \mathrm{N})$ contained in the ingested diet are effectively 
assimilated by the animals. For instance, most of the $\mathrm{N}$ in beech litter is incorporated in polyphenol-protein compounds (Berthelin et al., 1994).

This $\mathrm{N}$ form is not readily available to many microorganisms and invertebrates. These difficulties might be resolved using nutrient tracers such as stable isotopes $\left({ }^{13} \mathrm{C},{ }^{15} \mathrm{~N}\right)$ which assess the long-term assimilated nutrients. Variation of nitrogen stable isotope ratios $\left(\delta^{13} \mathrm{C}, \delta\right.$ ${ }^{15} \mathrm{~N}$ ) in soil animals recently appeared as a new and easy tool to analyse the long-term dietary preferences and the trophic position of soil animals along food chains, because the $\delta^{15} \mathrm{~N}$ of predators is about 3\% higher than that of herbivore or detritivore species (Minagawa and Wada, 1984; Peterson and Fry, 1987; Schmidt et al., 1997; Neilson et al., 2000; Ponsard and Arditi, 2000; Scheu and Falca, 2000; Oelbermann and Scheu, 2002).

Because large variations in $\delta^{15} \mathrm{~N}$ occur within each trophic level, Ponsard and Arditi (2000) and Scheu and Falca (2000) suggested that there were continuous gradients from primary to secondary decomposers, and from predators feeding predominantly on primary to predators feeding predominantly upon secondary decomposers (Scheu, 2002) rather than a theoretical trophic chain. However, results should be interpreted carefully, as $\delta^{15} \mathrm{~N}$ may vary with age of soil fauna (Owens, 1987; Ponsard and Averbuch, 1999; Adams and Sterner, 2000; Oelbermann and Scheu, 2002) and quality of the prey (Oelbermann and Scheu, 2002) and are site-specific (Neilson et al., 2000).

Food diets and prey-predator relationships may also be studied using stable isotope labelling. Briones et al. (1999) used substrates differing in their quality and their $\delta^{13} \mathrm{C}$ to investigate the relative contribution of mixtures of different substrates to animal nutrition.

In a coniferous forest with moder humus, Setälä and Aarnio (2002), using soil ${ }^{15} \mathrm{~N}$-labelling, showed that: 1) animals collected in surface litter layer (L layer) fed principally in this layer; 2) large and mobile fauna collected in $F$ and $H$ layers fed predominantly in the L layer; and 3) small sedentary taxa from $\mathrm{F}$ and $\mathrm{H}$ layers fed mostly in the layer in which they were collected. These results imply that foodwebs in moder humus were vertically stratified with little exchange between horizons, as suggested by Ponge (1999).

Based on these studies, we explored the combination of both natural isotope variation and isotopic labelling to get insight into the functional role of the soil fauna. This approach was applied to two beech forests differing in their humus form.

For this purpose, ${ }^{15} \mathrm{~N}$-labelled beech litter was deposited in December 2000 at two sites. We chose a chronosequence of four beech stands with mull humus at Leinefelde (Germany) and 
an old beech forest with moder humus at Sorø (Denmark). The biogeochemical cycles of carbon and nutrients at these two sites are intensively studied in the context of several European projects (FORCAST, 2000). After 9 months (September 2001), the fate of the tracer isotope was measured in litter and soil, as well as in soil animals. In parallel, natural ${ }^{15} \mathrm{~N}$ isotope variations in the soil fauna were measured. For each taxon, we calculated the proportion of ${ }^{15} \mathrm{~N}$ in the animal that was derived from the labelled substrate. Species were then ranked by the percentage of assimilated N, which was related to their mobility and their involvement in litter decomposition and $\mathrm{N}$ mineralisation.

\section{Material and methods}

\subsection{Site description}

The study was carried out in two beech (Fagus sylvatica L.) forests with contrasting humus types, the Leinefelde forest in Germany, and the Sorø forest in Denmark.

The site of Leinefelde, Thueringen (Germany), located $51^{\circ} 23^{\prime} \mathrm{N} ; 10^{\circ} 19^{\prime} \mathrm{E}$ at an altitude of $200 \mathrm{~m}$, is comprised of 4 adjacent beech stands of increasing age: $40 \mathrm{y}$ (L-1), $70 \mathrm{y}$ (L-2), $120 \mathrm{y}(\mathrm{L}-3)$ and $150 \mathrm{y}(\mathrm{L}-4)$. The parent material is limestone with loess deposit of varying depth. Soils vary over a short distance between loamy-clay Eutric Cambisols on limestone to loamy to clay-loamy Luvisols (FAO classification) on loess, presenting features of hydromorphy at $60-70 \mathrm{~cm}$ soil depth. The humus form is always a Mull. The L layer is spotted with many earthworms' casts. Soil $\mathrm{pH}$ in the $\mathrm{A}_{1}$ horizon varies in the range 6 to 7 (Mund, personal communication), depending on the depth of the loess cover.

The site of Sorø, located $55^{\circ} 29^{\prime} \mathrm{N} ; 1^{\circ} 38^{\prime} \mathrm{E}$ at an altitude of $20 \mathrm{~m}$, is an almost pure beech stand 100 y old. Soil is a sandy-loamy Dystric Cambisol (FAO classification), with a moder humus with well-developed L, F and H layers. A more detailed description of the sites can be found in FORCAST (2000).

\section{2. ${ }^{15} \mathrm{~N}$-labelled litter field experiment}

${ }^{15} \mathrm{~N}$-labelled senescent leaves were picked off at the end of November 1997 and 1998 from 12-year-old beech trees formerly enriched by spraying ${ }^{15} \mathrm{~N}$-labelled urea on their foliage (Zeller et al., 1998). The litter collected each year was air-dried; thoroughly mixed (12 kg) and 10 samples were analysed for $\mathrm{N}$ content and $\delta^{15} \mathrm{~N}$. The nutrient content of the labelled litter was close to that of the natural litter of the sites. The litter produced in the year 1997 with a $\delta^{15} \mathrm{~N}$ of $2580 \%$ was deposited at sites L-2 and L-3 and at Sorø, that collected in the 
year 1998, with a $\delta^{15} \mathrm{~N}$ of $1234 \%$, was deposited at sites L-1 and L-4 (Table 1). The initial N concentration in the labelled litter was $1.1 \% \mathrm{~N}$, about $10 \%$ of the total $\mathrm{N}$ was water-soluble. Eighteen grams of ${ }^{15} \mathrm{~N}$-labelled litter were introduced in plastic boxes $(25 \times 25 \times 2.5 \mathrm{~cm}$ length $\mathrm{X}$ width $\mathrm{x}$ height) closed with a $5 \mathrm{~mm}$ mesh size plastic net in order to allow almost all soil invertebrates to enter and free drainage. The nets were fixed at the bottom and at the top of each box. This amount $\left(290 \mathrm{~g} \mathrm{~m}^{-2}\right)$ represented about $3 / 4$ of the annual litterfall in the studied forests (FORCAST 2000). In December 2000, after main litterfall, 80 litter boxes (5 $\mathrm{m}^{2}$ ) were deposited at each stand in two parallel lines. Each line was $50 \mathrm{~cm}$ wide (two adjacent boxes) and $5 \mathrm{~m}$ long (20 adjacent boxes). The two lines were $1 \mathrm{~m}$ apart. The existing fresh L layer was carefully removed from the plot surface before deposition of the ${ }^{15} \mathrm{~N}$ labelled litter. At each site, 6 litter boxes were randomly collected in June 2001 for litter decomposition studies and in September 2001 for soil fauna and litter decomposition studies. The litter layer below the boxes (Lv layer) at Leinefelde and the F and $\mathrm{H}$ layers at Sorø, as well as 2 soil cores ( $8 \mathrm{~cm}$ diameter) of the $0-5 \mathrm{~cm}$ topsoil were collected in the field. 6 litter samples and 6 soil cores were also collected outside the labelled litter area at Leinefelde to study the natural $\delta^{15} \mathrm{~N}$ of soil fauna.

\subsection{Mass loss and $N$ dynamics}

Collected litter samples were carefully cleaned from adhering soil particles and plant residues, dried at $65^{\circ} \mathrm{C}$ to constant mass, weighed and ground in a ball mill before chemical analyses. $\mathrm{N}$ content and ${ }^{15} \mathrm{~N}$ isotopic abundance were measured. In this experiment we did not measure the input of particles into the boxes. But no fresh litter from the stands was deposited on the labelled litter boxes during the time of the experiment (December 2000 until September 2001). In June 2002, about 200 - $500 \mu \mathrm{g}$ white fungal hyphae were collected at the surface of decaying leaves at L-1 and L-2 sites and at Sorø.

\subsection{Soil fauna studies}

The soil mesofauna (Collembola, Oribatida, Gamasida and Enchytraeidae) and macrofauna (Diplopoda, Chilopoda, Isopoda, Araneae and Lumbicidae) were extracted from ${ }^{15} \mathrm{~N}$-labelled litter boxes, underlying litter layers and the $0-5 \mathrm{~cm}$ topsoil as well as from unlabelled samples (litter, 0-5 cm topsoil).

Animals were extracted using a two-step procedure:

1) enchytraeids were first extracted by the wet funnel method (O'Connor, 1955) then preserved in $95 \%$ ethanol; 
2) remaining samples were then transferred to a funnel closed by a $1.5 \mathrm{~mm}$ mesh size wire net. Arthropods (including macrofauna) and Lumbricidae were extracted by heat (Macfadyen, 1962) for 10 days. Soil fauna was collected in ethylene glycol then transferred to $95 \%$ ethanol after the extraction was completed. Storage for a short period in ethylene glycol, and for longer periods in ethanol had little effect on the $\delta^{15} \mathrm{~N}$ of soil arthropods (Fabiàn, 1998; Ponsard and Amlou, 1999).

Earthworms were also collected in the field when removing the litter boxes. Species extracted were Lumbricus sp. (juveniles), Allolobophora rosea, Aporectodea caliginosa at Leinefelde and Lumbricus sp. (juveniles), Lumbricus castaneus, Lumbricus rubellus, and Dendrobaena octaedra at Sorø.

Soil animals were separated under a dissecting microscope and determined to the genus or to the family level for Collembola, to the superfamily level for Oribatida and Gamasida, to the family level for Diplopoda and to the order level for Chilopoda, Isopoda and Araneae. This level of determination allowed separation of animals following a priori feeding preferences (fungivorous, coprophagous, saprophagous, herbifungivorous (pollen, micro-algae and fungal spores) within the decomposer compartment, and predators (Gunn and Cherrett, 1993; Walter and Proctor, 1999; Haq, 1981; Luxton, 1979; Behan and Hill, 1978; Poole, 1959). A list of the taxa analysed with their feeding preferences is given in the Appendix. Small microarthropods were transferred to tin capsules by pipetting them into ethanol then the alcohol was evaporated at $50^{\circ} \mathrm{C}$. Large animals were dried at $50^{\circ} \mathrm{C}$, ground in a ball mill then the powder was weighed in tin capsules. Capsules were stored in a desiccator until ${ }^{15} \mathrm{~N}$ analysis.

Fungal hyphae colonising the decomposing litter collected on June 2002 were sorted under a dissecting microscope, manually cleaned with distilled water to remove adhering litter and soil and their ${ }^{15} \mathrm{~N}$ content was measured.

\section{5. ${ }^{15} \mathrm{~N}$ analysis}

${ }^{15} \mathrm{~N}$ contents of litter, soil and animals were measured by an elemental analyser (Carlo Erba, NA1500-NC, Milano, Italy) coupled with a gas isotope mass spectrometer (Finnigan, delta-S, Bremen, Germany) by continuous flow (EA-CF-IRMS). ${ }^{15} \mathrm{~N}$ abundance is expressed as $\delta^{15} \mathrm{~N}$ units relative to atmospheric $\mathrm{N}_{2}$ as standard, according to the formula:

$$
\delta^{15} \mathrm{~N}(\%)=\left[\left(\mathrm{R}_{\text {sample }} / \mathrm{R}_{\mathrm{STD}}\right)-1\right] \times 1000 \text {, where } \mathrm{R} \text { is the }{ }^{15} \mathrm{~N} /{ }^{14} \mathrm{~N} \text { ratio. }
$$

An internal standard (labelled beech litter powder) of known isotopic composition $\left(\delta^{15} \mathrm{~N}=\right.$ $50 \%$ ) was measured after each batch of twelve samples, and used as a working standard to 
calibrate the mass spectrometer for labelled samples. Reliable measures of $\delta^{15} \mathrm{~N}$ for soil fauna were obtained for samples containing more than $10 \mu \mathrm{g} \mathrm{N}$, thus we grouped smallest animals to obtain $10-100 \mu \mathrm{g} \mathrm{N}$. As the $\mathrm{N}$ content of the fauna is close to $10 \%$, samples of 10 to 50 (depending on their size) microarthropods (Collembola, Oribatida, Gamasida and Uropodida) were needed for analyses. The animals extracted from the six replicates were bulked and three sub-samples were made when possible for isotopic analysis. For larger animals, 200-500 $\mu \mathrm{g}$ were weighed and replicates corresponded to individuals or groups of 2-3 individuals.

Gut contents of large earthworms were removed by the filter paper method (Dalby et al., 1996) and after dissection. For small animals, as their whole body was used for isotopic analysis, the presence of non-assimilated ${ }^{15} \mathrm{~N}$-labelled litter in the digestive tract may have caused a bias by artificially increasing the labelling rate of the animals.

The isotopic excess of detritivores and predators was calculated by subtracting the mean natural $\delta^{15} \mathrm{~N}$ value of the same animals collected in non-labelled areas $\left(\delta^{15} \mathrm{Nna}\right)$. At Leinefelde we used the natural abundance of animals from the L-2 stand. At Sorø we used the natural $\delta^{15} \mathrm{~N}$ values of the soil fauna previously studied at the site of Fougères (France), a beech forest stand with a moder humus similar to that of Sorø.

The proportion of litter-derived ${ }^{15} \mathrm{~N}$ in detritivores was calculated as the ratio of the animal isotopic excess to the mean ${ }^{15} \mathrm{~N}$ content of the enriched litter, before deposition in the field (December 2000) and at the time of collection (September 2001) for both Leinefelde and Sorø using the following equation:

$$
\text { assimilated } \mathrm{N} \text { by detritivores }=\frac{\delta^{15} \mathrm{~N} \text { detritivore }-\delta^{15} \mathrm{Nna} \text { detritivore }}{\delta^{15} \mathrm{~N} \text { deposited litter }-\delta^{15} \mathrm{~N} \text { collectedlitter }} \times 100(\%)
$$

where $\delta^{15} \mathrm{~N}$ detritivore being the $\delta^{15} \mathrm{~N}$ of the animals collected in the labelled litter boxes and $\delta^{15} \mathrm{Nna}$ detritivore being the natural $\delta^{15} \mathrm{~N}$ of the animals collected in the non-labelled area.

For predators we calculated the proportion of litter-derived ${ }^{15} \mathrm{~N}$, and the proportion of preyderived ${ }^{15} \mathrm{~N}$ using mean values of micro-detritivores (Collembola, Oribatida), for micropredators (Gamasida, Uropodida and Pseudoscorpionida) and the mean value of all detritivores for macropredators (Lithobiomorpha, Geophilomorpha, Araneae) using these equations: 
assimilated $\mathrm{N}$ by micropredators $=\frac{\delta^{15} \mathrm{~N} \text { micropredator }-\delta^{15} \mathrm{Nna} \text { micropredator }}{\text { mean } \delta^{15} \mathrm{~N} \text { of microdetritivores }} \times 100(\%)$

assimilmated $\mathrm{N}$ by macropredators $=\frac{\delta^{15} \mathrm{~N} \text { macropredator }-\delta^{15} \mathrm{Nna} \text { macropredator }}{\text { mean } \delta^{15} \mathrm{~N} \text { of detritivores }} \times 100(\%)$

The proportion of litter-derived nitrogen for the different soil taxa was analysed by two-way analysis of variance using the SAS General Linear Model (SAS Institute, 1995). Contrasts were employed for each taxon to test differences according to stand age and soil depth.

\section{Results}

\subsection{Litter decomposition}

\subsubsection{Leinefelde}

Within nine months, beech litter had lost between 27\% (L-1, L-2 and L-3) and 23\% (L-4) of its original weight while the total $\mathrm{N}$ content slightly decreased $(10 \%, \mathrm{~L}-1)$, remained almost stable (L-2 and L-3), or increased (7\%, L-4) compared to the original amount (Table 2).

Of the original $\mathrm{N}$ contained in the litter, $41 \%$ was lost at L-1, and about $20 \%$ at L-2, L-3 and L-4. This output was counterbalanced by the incorporation of $31 \%$ (L-1), 24\% (L-2, L-3) and $27 \%$ (L-4) external N, respectively (Table 2).

\subsubsection{Sorø}

Within nine months, beech litter had lost about $28 \%$ of its original weight while its total $\mathrm{N}$ content increased (20\%) compared to the original amount (Table 2).

Of the original $\mathrm{N}$ contained in the litter, $10.3 \%$ was lost. This output was counterbalanced by the incorporation of $31 \%$ of external N (Table 2).

As a consequence from this release of labelled litter $\mathrm{N}$, the $\delta^{15} \mathrm{~N}$ in the $\mathrm{Lv}$ and $\mathrm{F}$ layer switched from negative to positive values (Table 1). At Leinefelde the increase in soil $\delta^{15} \mathrm{~N}$ varied from $3.3 \%$ at L-4 to $9.7 \%$ at L-3 after nine months of litter decomposition.

\section{2. $\delta^{15} \mathrm{~N}$ of soil fauna}

Table 3 gives the natural isotopic abundance $\left(\delta^{15} \mathrm{~N}\right)$ of the different animal communities at the L-2 site. Values for detritivores ranged from $-3.1 \%$ (Lumbricus spp. juv) to $0.00 \%$ (Isopoda) 
Table 1. $\mathrm{N}$ concentration, water soluble $\mathrm{N}$ and $\delta^{15} \mathrm{~N}$ of the labelled litter and the organic soil layer just below the litter boxes (Lv at Leinefelde; $\mathrm{F}$ at Sorø). $\delta^{15} \mathrm{~N}$ of the labelled litter and the organic soil layer (Lv; F) after nine month of litter decomposition. Standard deviation from the mean in brackets.

\begin{tabular}{|c|c|c|c|c|c|c|c|}
\hline $\begin{array}{c}\text { Site } \\
\text { (stand age) }\end{array}$ & $\begin{array}{l}\text { Labelled litter } \\
\text { produced in }\end{array}$ & $\begin{array}{c}\text { Total N } \\
\text { (\%) }\end{array}$ & $\begin{array}{c}\text { Water soluble } \\
N \\
\text { (\% of total } N) \\
\end{array}$ & $\begin{array}{c}\delta^{15} \mathrm{~N} \\
\text { (litter) } \\
(\% \mathrm{o})\end{array}$ & $\begin{array}{c}\delta^{15} \mathrm{~N} \\
(\mathrm{Lv} ; \mathrm{F}) \\
(\%)\end{array}$ & $\begin{array}{c}\delta^{15} \mathrm{~N} \\
\text { (litter) } \\
(\%)\end{array}$ & $\begin{array}{c}\delta^{15} \mathrm{~N} \\
(\mathrm{Lv} ; \mathrm{F}) \\
(\%)\end{array}$ \\
\hline & \multicolumn{5}{|c|}{ initial } & \multicolumn{2}{|c|}{$\begin{array}{c}\text { after } 9 \text { months of } \\
\text { decomposition }\end{array}$} \\
\hline $\begin{array}{c}\text { Leinefelde-1 } \\
(40 \mathrm{y} .)\end{array}$ & 1998 & $\begin{array}{l}1.04 \\
(0.1)\end{array}$ & 10.5 & $\begin{array}{l}1234 \\
(127)\end{array}$ & $\begin{array}{l}-4.7 \\
(0.05)\end{array}$ & $\begin{array}{l}926 \\
(63)\end{array}$ & $\begin{array}{c}2.5 \\
(0.9)\end{array}$ \\
\hline $\begin{array}{l}\text { Leinefelde-2 } \\
\text { (70 y.) }\end{array}$ & 1997 & $\begin{array}{l}1.15 \\
(0.05)\end{array}$ & 10.1 & $\begin{array}{l}2580 \\
(187)\end{array}$ & $\begin{array}{c}-1.4 \\
(0.19)\end{array}$ & $\begin{array}{l}1983 \\
(60)\end{array}$ & $\begin{array}{c}7.6 \\
(2.3)\end{array}$ \\
\hline $\begin{array}{c}\text { Leinefelde-3 } \\
\text { (120 y.) }\end{array}$ & 1997 & $\begin{array}{l}1.15 \\
(0.05)\end{array}$ & 10.1 & $\begin{array}{l}2580 \\
(187)\end{array}$ & $\begin{array}{l}-1.6 \\
(0.16)\end{array}$ & $\begin{array}{l}1972 \\
(84)\end{array}$ & $\begin{array}{c}8.1 \\
(4.8)\end{array}$ \\
\hline $\begin{array}{c}\text { Leinefelde-4 } \\
(150 \text { y.) }\end{array}$ & 1998 & $\begin{array}{l}1.04 \\
(0.1) \\
\end{array}$ & 10.5 & $\begin{array}{l}1234 \\
(127) \\
\end{array}$ & $\begin{array}{c}-2.8 \\
(0.25) \\
\end{array}$ & $\begin{array}{l}864 \\
(47) \\
\end{array}$ & $\begin{array}{c}0.5 \\
(0.8) \\
\end{array}$ \\
\hline $\begin{array}{l}\text { Sorø } \\
(100 \mathrm{y} .)\end{array}$ & 1997 & $\begin{array}{c}1.15 \\
(0.05)\end{array}$ & 10.1 & $\begin{array}{l}2580 \\
(187)\end{array}$ & $\begin{array}{c}-2.7 \\
(0.24)\end{array}$ & $\begin{array}{l}1750 \\
(93)\end{array}$ & $\begin{array}{l}10.3 \\
(3.7)\end{array}$ \\
\hline
\end{tabular}

with a mean of $-1.9 \%$ (S.E. $=0.3, n=32)$ for all detritivores. Predator $\delta^{15} \mathrm{~N}$ varied between $1.2 \%$ (Lithobiomorpha) to $4.2 \%$ (Coleoptera) with a mean of $2.3($ S.E. $=0.2, n=38)$. (Figure 1).

In comparison to the $\delta^{15} \mathrm{~N}$ of the litter initially deposited (2580\%) and of the litter partly decomposed after nine months $(1983 \%)$, $\delta^{15} \mathrm{~N}$ values measured in the fauna extracted from labelled litter boxes at site L-2 were:

Lepidocyrtus: 236 to 282\%o, Folsomia 240 to 257\%o, Pogonognathellus 82 to 229\%, Nothroidea 67 to $126 \%$, Glomeridae 1 to $287 \%$, Parasitidae 82 to $196 \%$, Lithobiomorpha 1.4 to $13.0 \%$, Geophilomorpha -1 to $78 \%$, Araneae 3.3 to $31.6 \%$ (Table 3).

Measurements made on single large animals (Pogonognathellus, Lithobiomorpha, Geophilomorpha, and Diplopoda) showed large inter-individual variation, whereas bulk samples of small animals (Folsomia, Lepidocyrtus, Oribatid and Gamasid mites) presented smaller variation.

These results point out for almost all soil animals ${ }^{15} \mathrm{~N}$ contents larger than in the non-labelled area (background), implying that they ingested labelled litter or microorganisms feeding on labelled litter, and assimilated its heavy isotope nitrogen. The difference between the natural abundance and the ${ }^{15} \mathrm{~N}$ content in the labelled litter boxes gives an estimate of the proportion of animal $\mathrm{N}$ derived from litter. 
Table 2. Variation of remaining mass and total $\mathrm{N}$ in the litter after nine months of decomposition, at Leinefelde (beech chronosequence, mull) and Sorø (moder). $\mathrm{N}$ dynamics in the ${ }^{15} \mathrm{~N}$-labelled beech litter were calculated according to changes in the ${ }^{15} \mathrm{~N}$ enrichment of the litter. During the initial phase of litter decomposition the release of structural litter $\mathrm{N}$ is balanced by an incorporation of external $\mathrm{N}$. Values in brackets correspond to the standard error $(n=6)$. Means followed by the same letter in the columns did not differ significantly $(\mathrm{p}<0.01)$.

\begin{tabular}{|c|c|c|c|c|}
\hline Site & \multicolumn{4}{|c|}{$(\%$ of initial $)$} \\
\hline Leinefelde-1 (40 y.) & $\begin{array}{c}71.6 \mathrm{~b} \\
(1.7)\end{array}$ & $\begin{array}{c}90.3 \mathrm{~b} \\
(1.9)\end{array}$ & $\begin{array}{c}41.3 \mathrm{a} \\
(2.7)\end{array}$ & $\begin{array}{c}31.6 \mathrm{a} \\
(1.7)\end{array}$ \\
\hline Leinefelde-2 (70 y.) & $\begin{array}{c}73.2 \mathrm{~b} \\
(3.0)\end{array}$ & $\begin{array}{c}100.8 \mathrm{a} \\
(2.3)\end{array}$ & $\begin{array}{c}22.5 \mathrm{~b} \\
(2.3)\end{array}$ & $\begin{array}{c}23.4 \mathrm{~b} \\
(0.8)\end{array}$ \\
\hline Leinefelde-3 (120 y.) & $\begin{array}{c}73.8 \mathrm{~b} \\
(2.5)\end{array}$ & $\begin{array}{c}104.5 \mathrm{a} \\
(1.3)\end{array}$ & $\begin{array}{c}20.1 \mathrm{~b} \\
(1.9)\end{array}$ & $\begin{array}{c}24.6 \mathrm{~b} \\
(2.1)\end{array}$ \\
\hline Leinefelde-4 (150 y.) & $\begin{array}{c}77.2 \mathrm{a} \\
(0.9) \\
\end{array}$ & $\begin{array}{c}107.7 \mathrm{a} \\
(2.1) \\
\end{array}$ & $\begin{array}{l}19.3 \mathrm{~b} \\
(4.2) \\
\end{array}$ & $\begin{array}{c}27.1 \mathrm{~b} \\
(2.4) \\
\end{array}$ \\
\hline Sorø (100 y.) & $\begin{array}{l}71.6 \\
(1.2)\end{array}$ & $\begin{array}{c}120.7 \\
(2.8)\end{array}$ & $\begin{array}{l}10.3 \\
(2.7)\end{array}$ & $\begin{array}{l}31.0 \\
(1.7)\end{array}$ \\
\hline
\end{tabular}

\subsection{Proportion of $N$ originating from labelled litter}

\subsubsection{Leinefelde}

Hyphae of white-rot fungi isolated from decaying litter in June 2002 were variably enriched in ${ }^{15} \mathrm{~N}$. They had derived on average $14.0 \%($ S.E. $=3.9, n=4)$ of their nitrogen from decomposing labelled litter (Figure 2).

Faunal communities extracted from litter boxes at the four sites were largely similar, as observed outside litter boxes. However, some taxa, such as Neanuridae, Pseudosinella, Pogonognathellus, Sminthurinus, Isotomiella, Entomobrya, Achipteria, Uropodidae, Isopoda, Julidae, Geophilomorpha, were not extracted from all age classes of the chronosequence.

The proportion of $\mathrm{N}$ derived from labelled litter ranged from 0 to $15 \%$ in the different taxa (Figure 2). The age of the beech stand had no effect on the proportion of $\mathrm{N}$ originating from litter $(\mathrm{p}>0.05)$ for most soil fauna extracted from litter boxes, except for Glomeridae $(\mathrm{p}=$ 0.006), Enchytraeidae $(\mathrm{p}=0.003)$, Julidae $(\mathrm{p}=0.015)$ and Eniochthonius $(\mathrm{p}<0.001)$ which derived more $\mathrm{N}$ from litter in the younger stand (L-1) compared to others.

In the litter under the boxes the proportion of $\mathrm{N}$ originating from the labelled litter in the taxa Folsomia, Eniochthonius, Onychiuridae and Uropodidae was larger in the younger stands (L1 and / or L-2) compared to older ones, but inter-individual variation was large. 


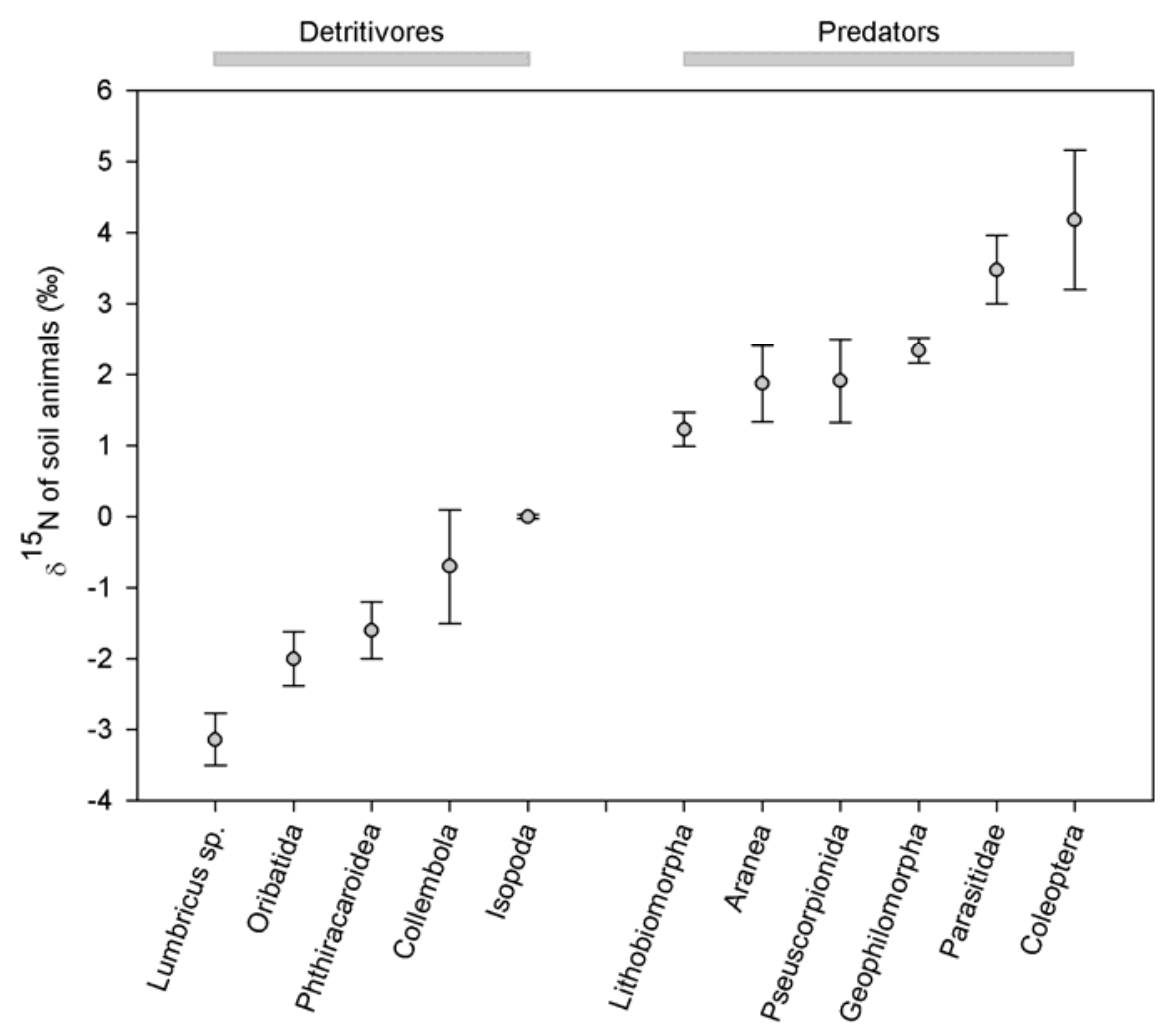

Figure 1. Variation in $\delta^{15} \mathrm{~N}$ in natural abundance of soil animals at site L-2

Soil fauna of the four stands (decomposers then predators) were ranked according to the amount of ${ }^{15} \mathrm{~N}$ assimilated from labelled litter into litter boxes (Figure 2). Three groups of decomposers and two groups of predators were separated:

- Detritivores:

(1) Taxa having derived more than $10 \%$ of their $\mathrm{N}$ from labelled litter:

The soil animals that were the most enriched in ${ }^{15} \mathrm{~N}$ were mainly small fungivorous (Eupodidae:14.6\%; Pseudosinella: 13.3\%), coprophagous (Isotomiella: 15.1\%; Folsomia: 11.4\%) and herbifungivorous grazers (Sminthurinus: 13.3\%).

When extracted from the litter under the boxes these animals derived less than $3 \%$ of their $\mathrm{N}$ from the above labelled litter.

(2) Taxa having derived 5 to $10 \%$ of their $\mathrm{N}$ from labelled litter:

These taxa were mostly saprophagous of variable size (Eniochthonius: 8.1\%, Glomeridae: 8.0\%, Enchytraeidae: $7.1 \%$ and Phthiracaroidea: 6.9\%); fungivorous and herbifungivorous (Lepidocyrtus: 9.3\%) and small litter browsers and suckers (Neanuridae: 9.1\%)

When extracted from the litter layer under the boxes, these taxa had derived less than $3 \%$ of their $\mathrm{N}$ from the above labelled litter. 
Table 3: ${ }^{15} \mathrm{~N}$ abundance $\left(\delta^{15} \mathrm{~N}\right)$ in soil fauna extracted from non labelled and labelled litter at the site L-2

\begin{tabular}{|c|c|c|c|c|}
\hline \multirow[b]{2}{*}{ Taxa } & \multicolumn{2}{|c|}{ In natural litter } & \multicolumn{2}{|c|}{ In the ${ }^{15} \mathrm{~N}$-labelled litter } \\
\hline & mean $\delta^{15} \mathrm{~N}$ & S.E. & mean $\delta^{15} \mathrm{~N}$ & S.E. \\
\hline DETRITIVORES & & & & \\
\hline Collembola (bulk) & -0.70 & $0.80(\mathrm{n}=3)$ & & \\
\hline Collembola & & & 268.2 & $14.4(n=3)$ \\
\hline Lepidocyrtus & & & & \\
\hline Collembola & & & 252.3 & $8.7(n=2)$ \\
\hline Folsomia & & & & \\
\hline Collembola & & & 146.5 & $44.5(n=3)$ \\
\hline Pogonognathellus & & & & \\
\hline Oribatida & -2.00 & $0.38(n=6)$ & 155.0 & $22.3(n=3)$ \\
\hline Phthiracaroidea & & & & \\
\hline Oribatida & -1.63 & $0.40(\mathrm{n}=5)$ & 100.1 & $(n=1)$ \\
\hline Belboidea & & & & \\
\hline Oribatida & & & 96.2 & $17.4(n=3)$ \\
\hline Nothroidea & & & & \\
\hline Lumbricus & -3.14 & $0.37(n=11)$ & & \\
\hline Isopoda & 0.00 & $0.03(n=6)$ & & \\
\hline Glomeridae & & & 137.0 & $83.3(n=3)$ \\
\hline Total detritivores & -1.88 & $0.28(n=32)$ & & \\
\hline PREDATORS & & & & \\
\hline Parasitidae & 3.48 & $0.48(n=6)$ & 137.6 & $21.3(n=5)$ \\
\hline Araneae & 1.87 & $0.54(\mathrm{n}=6)$ & 19.6 & $8.4(n=3)$ \\
\hline Lithobiomorpha & 1.23 & $0.24(n=10)$ & 6.7 & $4.3(n=3)$ \\
\hline Geophilomorpha & 2.34 & $0.18(n=10)$ & 41.3 & $23.0(n=3)$ \\
\hline Pseudoscorpionida & 1.91 & $0.59(n=3)$ & 50.6 & $(\mathrm{n}=1)$ \\
\hline Coleoptera & 4.18 & $0.98(n=3)$ & & \\
\hline Total predators & 2.26 & $0.21(n=38)$ & & \\
\hline
\end{tabular}

(3) Taxa having derived 1 to $5 \%$ of their $\mathrm{N}$ from labelled litter:

These soil animals were saprophagous Oribatida (Nothroidea: 4.7\%, Belboidea; 4.2\%, Achipteria: 4.1\%), large saprophagous (Julidae: $3.8 \%$, Isopoda: 3.2\%, and Lumbricidae: 1.2\%), and herbifungivorous Collembola (Entomobrya: $2.8 \%$, Pogonognathellus: $3.8 \%$ ) and Uropodidae $(4.1 \%)$.

When extracted from the underlying Lv layer, these taxa had derived 0.1\% (Belboidea, Julidae, Pogonognathellus) to $2.5 \%$ (Achipteria) of their $\mathrm{N}$ from the above labelled litter.

- Predators:

Micro-predator taxa (Trachytes) derived between 3\% to $8 \%$ of their $\mathrm{N}$ from labelled litter (Figure 2). When related to the mean labelling level of micro-detritivores (their prey), micropredators derived between $40 \%$ and $101 \%$ of their nitrogen from the prey available in the litter boxes (Table 3). Values larger than $100 \%$ are due to the fact that Trachytes fed on prey more labelled than average. 


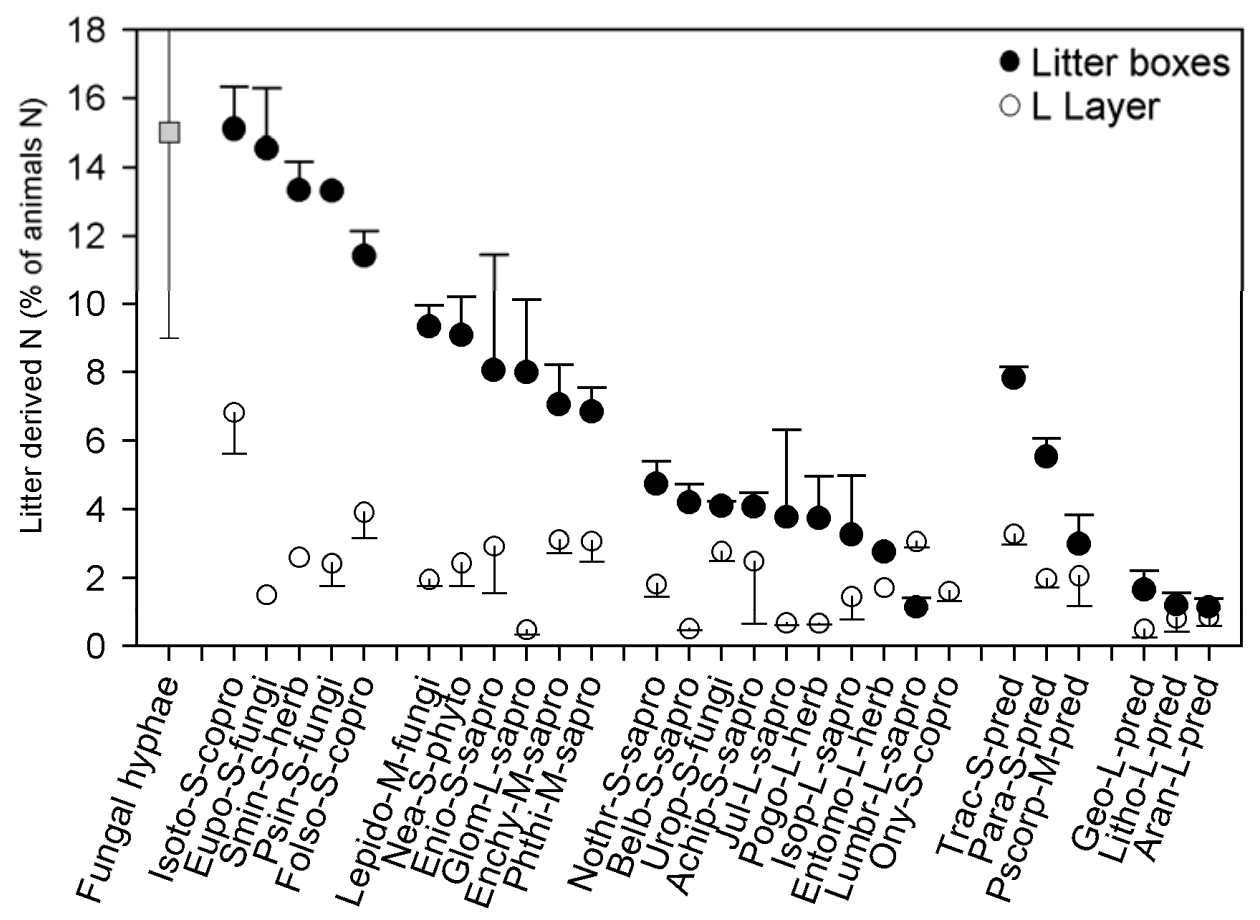

Figure 2. Litter derived $\mathrm{N}(\%$ of total animal $\mathrm{N}$ ) in the different soil animal taxa living in the labelled litter or in the decaying litter just below, at Leinefelde (all stands). Names, sizes and feeding preferences as in the Appendix.

Macro-predator taxa derived less than $2 \%$ of their $\mathrm{N}$ from labelled litter. When related to the mean label of detritivores, macro-predators derived between $15 \%$ and $22 \%$ of their nitrogen from the prey available in the litter boxes (Table 3).

Predators extracted from the decayed litter below the boxes assimilated less ${ }^{15} \mathrm{~N}$ but the difference was not significant $(\mathrm{p}>0.05)$.

In the $0-5 \mathrm{~cm}$ topsoil, detritivores and micro-predators derived a low proportion of their $\mathrm{N}$ from labelled litter (Collembola 1.3\%, Glomeridae 1.1\%, Isopoda 1.1\%, Oribatida 1.0\%, Enchytraeidae $0.4 \%$, Julidae $0 \%$, Gamasida 1.5\%). For macro-predators extracted from the 0 $5 \mathrm{~cm}$ topsoil the values were close to that obtained for animals collected in the litter boxes (Lithobiomorpha 2.9\%, Geophilomorpha 0.9\%).

In comparison, the Lv litter layer presented $\delta^{15} \mathrm{~N}$ values of less than $10 \%$ (between $0.5 \%$ at L-4 and 8.1\%o at L-3) and the 0-5 cm topsoil of less than of less than 5\%. Thus these horizons with $\delta^{15} \mathrm{~N}$ lower than that of the soil fauna provided low amounts of ${ }^{15} \mathrm{~N}$ to the soil animals (Table 1). 
Table 3: ${ }^{15} \mathrm{~N}$ abundance $\left(\delta^{15} \mathrm{~N}\right)$ in soil fauna extracted from non labelled and labelled litter at the site L-2

\begin{tabular}{|c|c|c|c|c|}
\hline \multirow[b]{2}{*}{ Taxa } & \multicolumn{2}{|c|}{ In natural litter } & \multicolumn{2}{|c|}{ In the ${ }^{15} \mathrm{~N}$-labelled litter } \\
\hline & mean $\delta^{15} \mathrm{~N}$ & S.E. & mean $\delta^{15} \mathrm{~N}$ & S.E. \\
\hline DETRITIVORES & & & & \\
\hline Collembola (bulk) & -0.70 & $0.80(n=3)$ & & \\
\hline Collembola & & & 268.2 & $14.4(n=3)$ \\
\hline Lepidocyrtus & & & & \\
\hline Collembola & & & 252.3 & $8.7(n=2)$ \\
\hline Folsomia & & & & \\
\hline Collembola & & & 146.5 & $44.5(n=3)$ \\
\hline Oribatida & -2.00 & $0.38(n=6)$ & 155.0 & $22.3(\mathrm{n}=3)$ \\
\hline Phthiracaroidea & & & & \\
\hline $\begin{array}{l}\text { Oribatida } \\
\text { Belboidea }\end{array}$ & -1.63 & $0.40(n=5)$ & 100.1 & $(\mathrm{n}=1)$ \\
\hline $\begin{array}{l}\text { Oribatida } \\
\text { Nothroidea }\end{array}$ & & & 96.2 & $17.4(\mathrm{n}=3)$ \\
\hline Lumbricus & -3.14 & $0.37(n=11)$ & & \\
\hline Isopoda & 0.00 & $0.03(n=6)$ & & \\
\hline Glomeridae & & & 137.0 & $83.3(n=3)$ \\
\hline Total detritivores & -1.88 & $0.28(n=32)$ & & \\
\hline PREDATORS & & & & \\
\hline Parasitidae & 3.48 & $0.48(n=6)$ & 137.6 & $21.3(\mathrm{n}=5)$ \\
\hline Araneae & 1.87 & $0.54(\mathrm{n}=6)$ & 19.6 & $8.4(n=3)$ \\
\hline Lithobiomorpha & 1.23 & $0.24(\mathrm{n}=10)$ & 6.7 & $4.3(n=3)$ \\
\hline Geophilomorpha & 2.34 & $0.18(\mathrm{n}=10)$ & 41.3 & $23.0(\mathrm{n}=3)$ \\
\hline Pseudoscorpionida & 1.91 & $0.59(\mathrm{n}=3)$ & 50.6 & $(\mathrm{n}=1)$ \\
\hline Coleoptera & 4.18 & $0.98(\mathrm{n}=3)$ & & \\
\hline Total predators & 2.26 & $0.21(n=38)$ & & \\
\hline
\end{tabular}

\subsubsection{Sorø}

Hyphae of white-rot fungi isolated from decaying litter in the boxes collected in June 2002 had derived on average $9.3 \%($ S.E. $=0.16, \mathrm{n}=3)$ of their nitrogen from decomposing litter (Figure 3).

Soil fauna were ranked according to the amount of ${ }^{15} \mathrm{~N}$ assimilated from the labelled litter, separately for decomposers and predators (Figure 3). Taxa derived on average less nitrogen from labelled litter than at Leinefelde. Two groups of decomposers and two groups of predators were separated:

- Detritivores:

(1) Taxa having derived 5 to $11 \%$ of their $\mathrm{N}$ from labelled litter:

These soil animals were mostly saprophagous of variable size (Enchytraeidae: 10.8\% Glomeridae: 10.1\%, and Phthiracaroidea: 6.1\%), herbifungivorous Collembola (Pogonognathellus: $7.8 \%$ ). 


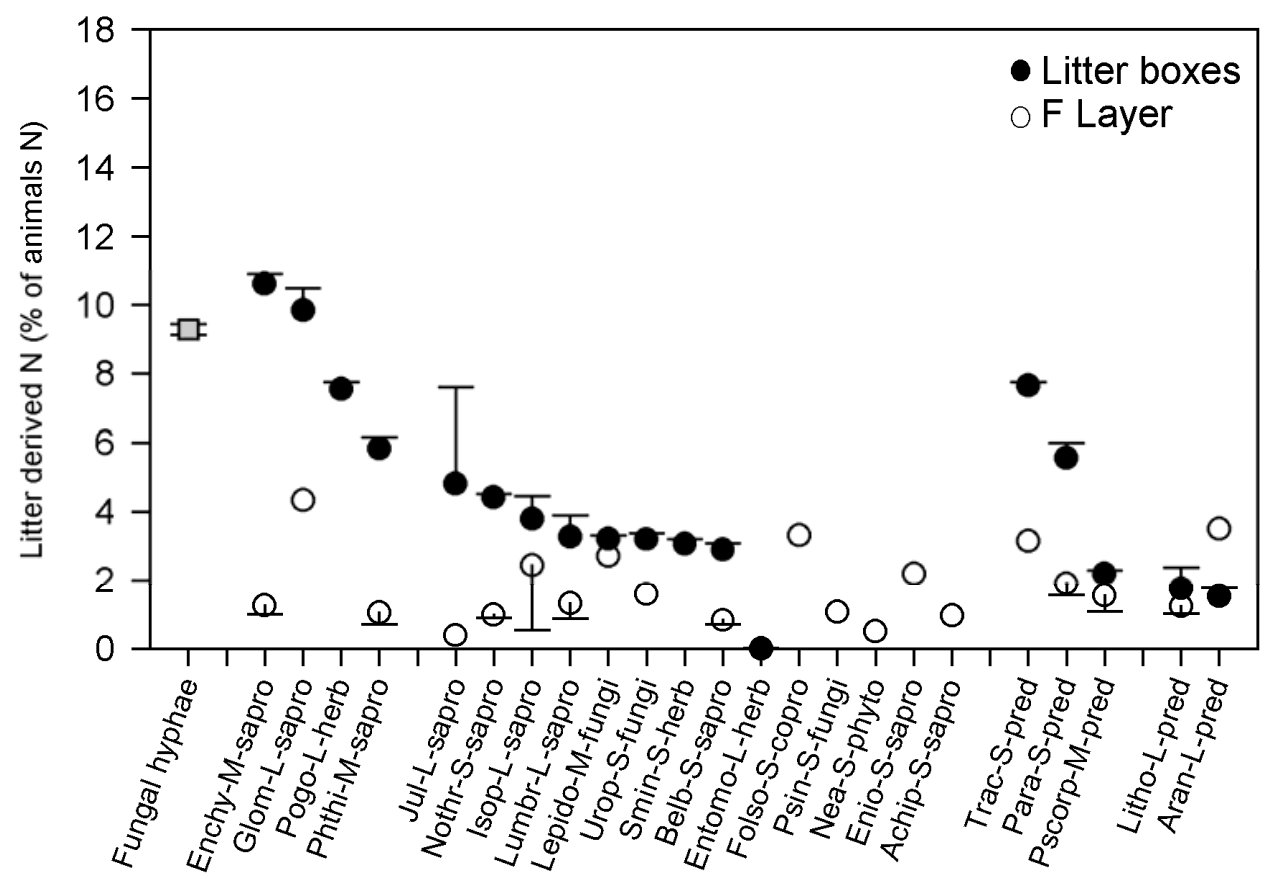

Figure 3. Litter derived $\mathrm{N}$ (\% of total animal $\mathrm{N}$ ) in the different soil animal taxa living in the labelled litter or in the decaying litter just below, at Sorø. Names, sizes and feeding preferences as in the Appendix.

When extracted from the $\mathrm{F}$ layer these taxa derived 1 to $4.5 \%$ of their $\mathrm{N}$ from the above placed labelled litter.

(2) Taxa having derived 0.1 to $5 \%$ of their $\mathrm{N}$ from labelled litter:

These soil animals were mostly herbivorous and fungivorous Oribatida (Nothroidea: 4.7\%; Belboidea: 3.2\%), fungivorous, and herbifungivorous Collembola (Lepidocyrtus: 3.5\%, Sminthurinus: 3.3\%; Entomobrya: 1.4\%) and Uropodidae (3.2\%).

When extracted from the $\mathrm{F}$ layer these soil animals derived between $1 \%$ and $3 \%$ of their $\mathrm{N}$ from the above placed labelled litter.

- Predators:

Micro-predator taxa derived between $2 \%$ to $7.6 \%$ of their $\mathrm{N}$ from labelled litter (Figure 3 ). When related to the mean labelling level of micro-detritivores, micro-predators derived between $50 \%$ and $177 \%$ of their nitrogen from prey available in the litter boxes (Table 4 ).

Values larger than $100 \%$ are due to the fact that Parasitidae and Trachytes fed on prey more labelled than the average. Macro-predator taxa derived less than $2 \%$ of their $\mathrm{N}$ from labelled litter (Figure 3). When related to the mean labelling level of detritivores, macro-predators derived between $21 \%$ and $27 \%$ of their nitrogen from prey available in the litter boxes (Table $4)$. 
Table 4: Percentage of nitrogen derived from prey in predators collected in the litter boxes. Mean and standard error in brackets

\begin{tabular}{|c|c|c|c|c|c|c|}
\hline & Parasitidae $^{*}$ & Trachytes $^{*}$ & $\begin{array}{c}\text { Pseudo- } \\
\text { scorpionida }^{*}\end{array}$ & $\begin{array}{l}\text { Lithobio- } \\
\text { morpha }^{\#}\end{array}$ & $\begin{array}{l}\text { Geophilo- } \\
\text { morpha }\end{array}$ & Araneae $^{\#}$ \\
\hline \multirow[t]{2}{*}{ Leinefelde } & $68.1(5.6)$ & $101.3(6.5)$ & $37.8(9.4)$ & $15.1(4.1)$ & $22.0(8.6)$ & $15.7(3.6)$ \\
\hline & $\mathrm{n}=13$ & $\mathrm{n}=4$ & $\mathrm{n}=9$ & $\mathrm{n}=12$ & $\mathrm{n}=5$ & $\mathrm{n}=10$ \\
\hline \multirow[t]{2}{*}{ Sorø } & $130.0(16.1)$ & $177.2(3.7)$ & $59.7(4.1)$ & $21.5(14.1)$ & - & $27.9(7.8)$ \\
\hline & $\mathrm{n}=4$ & $\mathrm{n}=2$ & $\mathrm{n}=3$ & $\mathrm{n}=3$ & - & $\mathrm{n}=3$ \\
\hline
\end{tabular}

*: calculation made using the mean labelling of microdetritivores (Collembola, Oribatida), see equations in the text. " : calculation made using the mean labelling of all detritivores

Predators extracted from the $\mathrm{F}$ layer assimilated less ${ }^{15} \mathrm{~N}$ but the difference was not significant $(\mathrm{p}>0.05)$.

In the $\mathrm{H}$ layer detritivores derived 0.8 to $1.6 \%$, and predators $0.3 \%$ to $3.0 \%$ of their $\mathrm{N}$ from labelled litter. In the $0-5 \mathrm{~cm}$ soil layer, Enchytraeidae and Oribatida derived respectively 0.8 and $0.7 \%$, and predators derived 0.6 to $1.2 \%$ of their $\mathrm{N}$ from labelled litter. For micropredators the values are not significantly different from those of the F layer.

$\mathrm{F}$ and $\mathrm{H}$ layers showed $\delta^{15} \mathrm{~N}$ values of $10.4 \%$ and $4.1 \%$, respectively which are lower to the animals ones; thus they provided a low amount of ${ }^{15} \mathrm{~N}$ to the soil fauna extracted in these layers, as in the Leinefelde site.

\section{Discussion}

During the course of litter decomposition, $\mathrm{N}$ release is balanced by the accumulation of external $\mathrm{N}$ through several processes such as immigration of fauna and fungi and throughfall deposition (Berg 1988; Zeller et al., 2000). The role of white-rot fungi in the input of external $\mathrm{N}$ was clearly shown by Zeller et al. 2000 using combined ${ }^{15} \mathrm{~N}$ and ergosterol analysis. It is confirmed in this experiment by the relatively low label of the white fungi compared to that of the decaying labelled litter. It is likely that a large part of the fungal biomass present in the boxes derived its nitrogen from external sources, especially basidiomycetes which may exploit a large volume of litter and soil (Brownlee et al., 1983; Thompson, 1984).

Results in natural ${ }^{15} \mathrm{~N}$ abundance showed that earthworms are the most ${ }^{15} \mathrm{~N}$ depleted soil animals, which is in agreement with their classification as primary decomposers. Collembola and Oribatida showed a large range of values in relation with their feeding behaviour; they feed on substrates with different ${ }^{15} \mathrm{~N}$ content such as leaves, faecal pellets, decomposer fungi 
hyphae, mycorhiza fungal hyphae, and bacteria. The predators, as expected, are more enriched in ${ }^{15} \mathrm{~N}$. Gamasida and Coleoptera are the most enriched soil animals from this site.

The values obtained at the Leinefelde site showed a gradient from primary decomposers and secondary decomposers to primary and secondary predators (Figure 1), similar to the gradients observed in two previous studies on natural ${ }^{15} \mathrm{~N}$ abundance of soil animals (Scheu and Falca, 2000; Ponsard and Arditti, 2000).

The $4.2 \%$ difference obtained between the mean of the detritivores $(-1.9 \%$ o $)$ and the mean of predators $(2.3 \%)$ is larger than $3.4 \%$ which is defined as the theoretical increase between two successive trophic levels (Minagawa and Wada, 1984) suggesting that there is more than one trophic level between detritivores and predators or that animals had various ages. This feature is also in good agreement with findings by Ponsard and Arditti (2000) and Scheu and Falca (2000) who attributed it either to intra-guild predation or to the fact that predators predominantly feed on secondary decomposers.

The range of ${ }^{15} \mathrm{~N}$ content of soil animals collected in the labelled litter suggest that they assimilated nitrogen from labelled litter to different extent in relation to their mobility and diet. The suggestion that the proportion of assimilated nitrogen can be used as an indicator of the involvement of soil animals in the decomposition of litter is based on the following assumptions:

- the life-span of most soil animals is shorter than 9 months (Van der Drift, 1951), although this may not be true for earthworms and oribatids. Hence, $\mathrm{N}$ assimilated from labelled litter should not be diluted in a pool of unlabelled $\mathrm{N}$ assimilated before deposition of labelled litter.

- the mobility of soil animals of the same size and feeding behaviour is comparable. In fact, the labelling of animals with different mobilities cannot be easily compared because more mobile forms may have fed partly outside the labelled litter boxes.

- animals that ingest and digest more $\mathrm{N}$ originating from ${ }^{15} \mathrm{~N}$-labelled litter will present larger enrichment in ${ }^{15} \mathrm{~N}$. Ingestion without digestion should not increase the animal label.

At the Leinefelde site, during the time of the experiment, detritivores derived up to $15.1 \%$ (for the Collembolan Isotomiella) of their nitrogen from decomposing litter and on average $9.4 \%$ (S.E. $=0.6, \mathrm{n}=44)$ for Collembola, $7.1 \%($ S.E. $=1.2, \mathrm{n}=10)$ for Enchytraeidae, $6.8 \%$ $($ S.E. $=1.7, \mathrm{n}=14)$ for Diplopoda, $5.5 \%($ S.E. $=0.5, \mathrm{n}=39)$ for oribatid mites and $3.3 \%$ (S.E. $=1.7, \mathrm{n}=5)$ for Isopoda. 
At the site of Sorø, during the time of the experiment, soil fauna derived a lower proportion of their nitrogen from decomposing beech litter, most labelled taxa (Enchytraeidae) deriving at most $11.7 \%$ of their $\mathrm{N}$ from labelled litter. The average proportion of litter derived nitrogen was $10.8 \%($ S.E. $=2.9, \mathrm{n}=3)$ for Enchytraeidae, 8.0\% (S.E. $=1.9, \mathrm{n}=5)$ for Diplopoda, $4.6 \%$ $(\mathrm{S} . \mathrm{E} .=0.4, \mathrm{n}=11)$ for Oribatida, 4.1\% (S.E. $=0.6, \mathrm{n}=3)$ for Isopoda and 4.0\% $($ S.E. $=0.8, \mathrm{n}=11)$ only for Collembola.

Earthworms derived a low amount of their nitrogen from labelled litter in both sites. This low ${ }^{15} \mathrm{~N}$ content might be related to their weight, which implies the ingestion of a large amount of labelled litter before their $\delta^{15} \mathrm{~N}$ increases above background level, but also to their wandering movements which make them able to ingest food taken in different horizons (Bernier, 1998). Hence, fresh litter does not appear to be directly the main $\mathrm{N}$ source for the soil animals collected in the boxes as they derived less than $15 \%$ of their nitrogen from the labelled fresh litter present in the boxes during the nine months of the experiment.

Firstly, this surprisingly low rate of assimilation of $\mathrm{N}$ might be related to the mobility of the fauna. Labelled litter covered about $50 \%$ of the square meter area surrounding each litter box. The effect of mobility is very clear in the predator group at both Leinefelde and Sorø. However, this holds only for large detritivores and macro-predators, as small animals collected under the boxes were distinctly less labelled, pointing to a low level of vertical displacement. The $\delta^{15} \mathrm{~N}$ of small predators was high and on average close to that of their prey, which indicated that the immigration rate of small predators was low. Contrastingly, the $\delta^{15} \mathrm{~N}$ of large predators was very low and extremely variable from one to another individual, probably because some of these animals fed outside the litter boxes. For the same reason, the $\delta^{15} \mathrm{~N}$ of large detritivores was lower than that of small detritivores with similar feeding preferences.

The main reason for the low rate of ${ }^{15} \mathrm{~N}$ labelling of soil fauna could be found in the selection of food resources within the boxes:

- At the Leinefelde site on mull humus the soil animals which derived the largest proportion of their $\mathrm{N}$ from labelled litter were small fungivorous and saprophagous species. The ${ }^{15} \mathrm{~N}$ content of these animals was close to that of fungal hyphae collected in June 2002.

- In contrast, at the site of Sorø, on moder humus, the taxa which derived a larger proportion of their nitrogen from decomposing litter were saprophagous species such as 
Enchytraeidae, Diplopoda, Phthiracaroidea and other Oribatida which eat fresh and decomposed litter (Hayes, 1965; David, 1987; Ponge, 1999).

These results suggest that the detritivore community used different sources and to a different extent in these two contrasted humus types:

- At the mull site (Leinefelde) it is likely that the whole community of detritivores assimilated nitrogen preferentially from microorganisms colonising fresh litter or from faecal pellets of non-litter origin, rather than from litter itself.

- At the moder site (Sorø), litter-feeding taxa derived the larger proportion of nitrogen directly from the decomposing litter or from faecal pellets of litter origin.

These differences can be explained by the relative contribution of mesofauna, compared to macrofauna, in the disintegration of litter in both humus types (Bocock, 1964; Herlitzius, 1987; Staaf, 1987; Ponge et al., 1997).

In mull humus, most litter is processed by large animals such as earthworms, slugs, millipedes and woodlice, which are actively moving throughout litter and soil and thus diluted the heavy isotope in our experiment as mentioned by Binet and Trehen (1992), and by saprophagous fungi (Toutain, 1987). In this humus type, small animals mainly browse on microbial colonies and tunnel faeces of macroinvertebrates (Zachariae, 1965; Toutain et al., 1982; Didden, 1990).

In moder humus, most litter is processed by small animals, which may pass through several animal guts before being incorporated into stable humus, forming the H layer (Ponge, 1991b).

The feeding preference of detritivores is still a matter of debate, as contradictory observations have been made. It has been often shown that saprophagous species feed principally on microorganisms colonising the litter (Luxton, 1966; Dash and Cragg, 1972; Mitchell and Parkinson, 1976; Visser and Whittaker, 1977; Parkinson et al., 1979; Whittaker, 1981; Verhoef et al., 1988; Ponge, 1991a; Kaneko et al., 1995; Maraun et al., 1998; Scheu and Schaeffer, 1998). On the other hand, Ponsard and Arditi (2000) and Scheu and Falca (2000), using natural isotope ratios, showed that the natural $\delta^{15} \mathrm{~N}$ of detritivores was close to that of beech litter of the L layer, and suggested that structural components of the litter (L, F) layers rather than hydrosolubles were likely the main food source for soil fauna. Ponge (1991a, 1999), using the direct observation of gut contents of animals collected in different litter horizons, considered enchytraeids as primary consumers of needle and leaf litter in moder humus, contrary to the opinion expressed by Zachariae (1965) who considered them as secondary decomposers. Briones and Ineson (2002) using ${ }^{14} \mathrm{C}$ dating of enchytraieds to 
investigate their feeding behaviour in mor humus showed that they assimilated carbon from organic matter 5-10 years old.

Our experiment showed that soil fauna assimilated low $\mathrm{N}$ from the decaying litter and rather suggest that $\mathrm{N}$ was assimilated from fungi colonising the litter or faecal pellets as their $\delta^{15} \mathrm{~N}$ was close to that of the soil fauna. In comparison, soil predators appeared closely linked for their $\mathrm{N}$ supply to detritivores onto which they prey. The above mentioned contradiction can be resolved by considering that the litter found in the L layer is not only made of raw plant material, since a large part has been already transformed by the internal microflora of decomposing beech leaves (Reisinger et al., 1978). In particular, foliar nitrogen, which is immobilised by $\mathrm{N}$-demanding microorganisms, becomes rapidly incorporated into the microbial biomass (Berg and Söderström, 1979). Thus the identity between the natural $\delta^{15} \mathrm{~N}$ of beech leaves of the L layer and that of litter-feeding animals cannot give evidence that they have consumed beech litter.

Soil fauna from the mull sites assimilated a larger proportion of nitrogen from the decomposing litter than fauna from the moder site whereas mass losses were in the same range. We may thus suggest that mull humus release more efficiently $\mathrm{N}$ than moder humus during decomposition and that the passage of nitrogen from plant biomass to animal biomass is faster in mull than in moder. This is in accordance with ideas developed by Staaf (1987), Schaefer and Schauermann (1990) and Ponge (2003) on the faster circulation of nutrients in mull humus compared to moder humus.

Finally, the soil foodwebs of the studied forests appeared to be vertically stratified, at least for microdetritivores and for micropredators, as animals found beneath the experimental boxes derived less nitrogen from labelled litter than animals found in the boxes. This does not mean that no exchange took place between fresh litter and underlying horizons, since all animals collected under the boxes exhibited a ${ }^{15} \mathrm{~N}$ enrichment compared to the horizon into which they were collected. However, we cannot know whether this enrichment was due to movements of animals or to translocation of ${ }^{15} \mathrm{~N}$ by fungal mycelia.

In conclusion, the use of ${ }^{15} \mathrm{~N}$ enriched litter and ${ }^{15} \mathrm{~N}$ analysis of soil fauna appears as an interesting tool to trace the fate of nitrogen within the soil food web. The data so far obtained enabled us to discuss the "functional role" of soil microbes and fauna in the transformation of litter nitrogen. However, conclusions of this experiment were not as strong as we expected because the limited area covered by the labelled litter allowed mobile soil animals (predators) to feed outside the labelled area. Improvements could be obtained by experimenting in controlled conditions. Because extraction and identification of soil fauna needs a lot of time, 
we did it only once and studied the whole range of soil animals. Another suggestion from this experiment would be to select a few important taxa and follow the progressive incorporation, assimilation and transformation of litter $\mathrm{N}$ with time. The combination of this method with population studies on soil fauna should help us to get further insight into the transfer of nutrients and energy processing in the soil foodweb during litter decomposition.

\section{Acknowledgements}

This study received financial support from the EC through the project FORCAST (EVK2CT1999-00035). We thank two anonymous reviewers for their constructive comments on the manuscript.

\section{References}

Adams, T.S., Sterner, R.W., 2000. The effect of dietary nitrogen content on trophic level ${ }^{15} \mathrm{~N}$ enrichment. Limnology and Oceanography 45, 601-607.

Behan, V.M., Hill, S. B., 1978. Feeding habits and spore dispersal of oribatid mites in the North American Arctic. Revue d'Ecologie et de Biologie du Sol 15, 497-516.

Behan Pelletier, V.M., Hill, S. B. 1983. Feeding habits of sixteen species of Oribatei (Acari) from an acid peat bog, Glenamoy, Ireland. Revue d'Écologie et de Biologie du Sol 20, 221-267.

Berg, B. 1988. Dynamics of nitrogen $\left({ }^{15} \mathrm{~N}\right)$ in decomposing Scots pine needle litter. Long term decomposition in a Scots pine forest. VI. Canadian Journal of Botany 66, 15391546.

Berg, B., Söderström, B. 1979. Fungal biomass and nitrogen in decomposing Scots pine needle litter. Soil Biology and Biochemistry 11, 339-341.

Bernier, N., 1998. Earthworm feeding activity and development of the humus profile. Biology and Fertility of Soils 26, 215-223.

Berthelin, J., Leyval, C., Toutain, F. (1994) Biologie des sols. Rôle des organismes dans l'altération et l'humification. In: Bonneau, M. et Souchier, B. (eds) Pédologie 2. Constituants et propriétés du sol. Masson, Paris, pp 143-237.

Binet, F. Trehen, 1992. Experimental microcosm study of the role of Lumbricus terrestris (Oligochaeta: Lumbricidae) on nitrogen dynamics in cultivated soils. Soil Biology and Biochemistry 24, 1501-1506. 
Bocock, K.L., 1964. Changes in the amounts of dry matter, nitrogen, carbon and energy in decomposing woodland leaf litter in relation to the activities of the soil fauna. Journal of Ecology 52, 273-284.

Briones, M. J. I., Ineson, P. 2002. Use of ${ }^{14} \mathrm{C}$ carbon dating to determine feeding behaviour of enchytraeids. Soil Biology and Biochemistry 34, 881-884.

Briones, M.J.I., Ineson, P., Sleep, D. 1999. Use of $\delta^{13} \mathrm{C}$ to determine food selection in collembolan species. Soil Biology and Biochemistry 31, 937-940.

Brownlee, C., Duddridge, J.A., Malibari, A., Read, D.J., 1983. The structure and function of mycelial systems of ectomycorrhizal roots with special reference to their role in forming inter-plant connections and providing pathways for assimilate and water transport. Plant and Soil 71, 433-443.

Dalby, P.R., Baker, G.H., Smith, S.E., 1996. "Filter paper method" to remove soil from earthworm intestine and to standardise the water content of earthworm tissue. Soil Biology and Biochemistry 28, 685-687.

Dash, M.C., Cragg, J.B., 1972. Selection of microfungi by Enchytraeidae (Oligochaeta) and other members of the soil fauna. Pedobiologia 12, 282-286.

David, J.F., 1987. Consommation annuelle d'une litière de chêne par une population adulte du diplopode Cylindroiulus nitidus. Pedobiologia 30, 299-310.

Didden, W.A.M., 1990. Involvment of Enchytraeidae (Oligochaeta) in soil structure evolution in agricultural fields. Biology and Fertility of Soils 9, 152-158.

Fabián, M., 1998. The effects of different methods of preservation on the ${ }^{15} \mathrm{~N}$ concentration in Folsomia candida (Collembola). Applied Soil Ecology 9, 101-104.

FORCAST, 2000. Forest Carbon - Nitrogen Trajectories. http: //www.bgc.mpg.de/public/carboeur/Forcast/index_for.html.

Gunn, A., Cherrett, J.M., 1993. The exploitation of food resources by soil meso- and macro invertebrates. Pedobiologia 37, 303-320.

Haq, M.A., 1981. Feeding habits of ten species of oribatid mites (Acari: Oribatei) from Malabar, South India. Indian Journal of Acarology 6, 39-50.

Hayes, A.J., 1965. Studies on the distribution of some phthiracarid mites (Acari, Oribatidae) in a coniferous forest soil. Pedobiologia 5, 252-261.

Hendriksen, N.B., 1990. Leaf litter selection by detritivore and geophagous earthworms. Biology and fertility of Soil 10, 17-21. 
Herlitzius, H., 1987. Decomposition in five woodland soil, relationships with some invertebrate populations and with weather. Biology and Fertility of Soils 3, 85-89.

Kaneko, N., McLean, M.A., Parkinson, D., 1995. Grazing preference of Onychiurus subtenuis (Collembola) and Oppiella nova (Oribatei) for fungal species inoculated on pine needles. Pedobiologia 39, 538-546.

Klironomos, J.N., Widden, P., Deslandes, L., 1992. Feeding preferences of the collembolan Folsomia candida in relation to microfungal succession on decaying litter. Soil Biology and Biochemistry 24, 685-692.

Luxton, M., 1966. Laboratory studies on the feeding habits of saltmarsh Acarina, with notes on their behaviour. Acarologia 8, 163-175.

Luxton, M., 1979. Food and energy processing by oribatid mites. Revue d'Ecologie et de Biologie du Sol 16, 103-111.

Macfadyen, A., 1962. Soil arthropod sampling. Advances in Ecological Research 1, 1-34.

Maraun, M., Migge, S., Schaeffer, M., Scheu, S., 1998. Selection of microfungal food by six oribatid mite species (Oribatida, Acari) from two different beech forests. Pedobiologia $42,232-240$.

Minagawa, M., Wada, E., 1984. Stepwise enrichment of ${ }^{15} \mathrm{~N}$ along food chains, further evidence and the relation between $\delta^{15} \mathrm{~N}$ and animal age. Geochimica et Cosmochimica Acta 50, 2143-2146.

Mitchell, M., Parkinson, D., 1976. Fungal feeding of oribatid mites (Acari: Cryptostigmata) in an aspen woodland. Ecology 57, 302-312.

Neilson, R., Boag, B., Smith, M., 2000 Earthworm $\delta^{13} \mathrm{C}$ and $\delta^{15} \mathrm{~N}$ analyses suggest that putative functional classifications of earthworms are site-specific and may also indicate habitat diversity. Soil Biology and Biochemistry 32, 1053-1061

O’Connor, F.B., 1955. Extraction of enchytraeid worms from a coniferous forest soil. Nature $175,815-816$.

Oelbermann, K., Scheu, S., 2002. Stable isotope enrichment $\left(\delta^{15} \mathrm{~N}\right.$ and $\left.\delta^{13} \mathrm{C}\right)$ in a generalist predator (Pardosa lugubris, Araneae: Lycosidae): effects of prey quality. Oecologia $130,337-344$.

Owens, N.J.P., 1987. Natural variations in ${ }^{15} \mathrm{~N}$ in the natural environment. Advances in Marine Biology 24, 389-451.

Parkinson, D., Visser, S., Whittaker, J.B., 1979. Effects of Collembola grazing on fungal colonization of leaf litter. Soil Biology and Biochemistry 11, 529-535. 
Peterson, B.J., Fry, B., 1987. Stable isotopes in ecosystem studies. Annual Review of Ecology and Systematics 18, 293-320.

Ponge, J.F., 1991a. Food resources and diets of soil animals in a small area of Scots pine litter. Geoderma 49, 33-62.

Ponge, J.F., 1991b. Succession of fungi and fauna during decomposition of needles in a small area of Scots pine litter. Plant and Soil 138, 99-113.

Ponge, J.F., 1999. Horizons and humus forms in beech forests of the Belgian Ardennes. Soil Science Society of America Journal 63, 1888-1901.

Ponge, J.F., 2003. Humus forms in terrestrial ecosystems: a framework to biodiversity. Soil Biology and Biochemistry 35, 935-945.

Ponge, J.F., Arpin, P., Sondag, F., Delecour, F., 1997. Soil fauna and site assessment in beech stands of the Belgian Ardennes. Canadian Journal of Forest Research 27, 2053-2064.

Ponsard, S., Amlou, M., 1999. Effects of several preservation methods on the isotopic content of Drosophila samples. Comptes Rendus de l'Académie des Sciences, Série III, 322, $35-41$.

Ponsard, S., Arditi, R., 2000. What can stable isotopes $\left(\delta^{15} \mathrm{~N}\right.$ and $\left.\delta^{13} \mathrm{C}\right)$ tell about the food web of soil macro-invertebrates? Ecology 81, 852-864.

Ponsard, S., Averbuch, P., 1999. Should growing and adult animals fed on the same diet show different $\delta^{15} \mathrm{~N}$ values? Rapid Communications in Mass Spectrometry 13, 1305-1310.

Poole, T.B., 1959. Studies on the food of Collembola in a Douglas fir plantation. Proceedings of the Zoological Society of London 132, 71-82.

Reisinger, O., Toutain, F., Mangenot, F., Arnould, M.F., 1978. Étude ultrastructurale des processus de biodégradation. I. Pourriture blanche des feuilles de hêtre (Fagus sylvatica L.). Canadian Journal of Microbiology 24, 725-733.

SAS Institute, 1995. Statistical Analysis System User's Guide, Version 6.10. SAS Institute Inc., Cary.

Saur, E., Ponge, J.F., 1988. Alimentary studies on the Collembolan Paratullbergia callipygos using transmission electron microscopy. Pedobiologia 31, 355-379.

Schaefer, M., Schauermann, J., 1990. The soil fauna of beech forests: comparison between a mull and a moder. Pedobiologia 34, 299-314.

Scheu, S., 2002. The soil food web: structure and perspectives. European Journal of Soil Biology 38, 11-20. 
Scheu, S., Falca, M., 2000. The soil food web of two beech forests (Fagus sylvatica) of contrasting humus type: stable isotope analysis of a macro- and a mesofauna-dominated community. Oecologia 123, 285-296.

Scheu, S., Schaeffer, M., 1998. Bottom-up control of the soil macrofauna community in a beech wood on limestone: manipulation of food resources. Ecology 79, 1573-1585.

Schmidt, O., Scrimgeour, C.M., Handley, L.L., 1997. Natural abundance of ${ }^{15-} \mathrm{N}$ and ${ }^{13-} \mathrm{C}$ in earthworms from a wheat and a wheat-clover field. Soil Biology and Biochemistry 29, $1301-1308$

Setälä, H., Aarnio, T., 2002. Vertical stratification and trophic interactions among organisms of a soil decomposer food web: a field experiment using ${ }^{15} \mathrm{~N}$ as a tool. European Journal of Soil Biology 38, 29-34.

Shaw, P.J.A., 1988. A consistent hierarchy in the fungal feeding preferences of the Collembola Onychiurus armatus. Pedobiologia 31, 179-187.

Staaf, H., 1987. Foliage litter turnover and earthworm populations in three beech forests of contrasting soil and vegetation types. Oecologia 72, 58-64.

Stöckli, H., 1990. Das Unterscheidungsvermögen von Porcellio scaber (Crustacea, Isopoda) zwischen Blättern einer Baumart, unter Berücksichtigung der makroskopisch sichtbaren Verpilzung. Pedobiologia 34, 191-205.

Thompson, W., 1984. Distribution, development and functioning of mycelial cord systems of decomposer basidiomycetes of the deciduous woodland floor. In: Jennings, D.H., Rayner, A.D.M. (Eds.), The ecology and physiology of the fungal mycelium. Cambridge University Press, Cambridge, UK, pp. 185-214.

Toutain, F. 1987. Activité biologique des sols, modalités et lithodépendance. Biology and Fertility of Soils 3, 31-38.

Toutain, F., Villemin, G., Albrecht, A., Reisinger, O., 1982. Étude ultrastructurale des processus de biodégradation. II. Modèle enchytraeides-litière de feuillus. Pedobiologia $23,145-156$.

Van der Drift, J., 1951. Analysis of the animal community in a beech forest floor. Tijdschrift voor Entomologie 49, 1-168.

Verhoef, H.A., Prast, J.E., Verweij, R.A., 1988. Relative importance of fungi and algae in the diet and nitrogen nutrition of Orchesella cincta (L.) and Tomocerus minor (Lubbock) (Collembola). Functional Ecology 2, 195-201.

Visser, S., Whittaker, J.B., 1977. Feeding preference for certain fungi by Onychiurus subtenuis (Collembola). Oikos 29, 320-325. 
Walter, D.E., Proctor, H.C., 1999. Mites: Ecology, Evolution and Behaviour, University of NSW Press/CABI, Sydney/Wallingford, 322 pp.

Whittaker, J.B., 1981. Feeding of Onychiurus subtenuis (Collembola) at snow melt in aspen litter in the Canadian Rocky Mountains. Oikos 36, 203-206.

Zachariae, G., 1965. Spuren tierischer Tätigkeit im Boden des Buchenwaldes. Forstwissenschaftliche Forschungen 20, 1-68.

Zeller, B., Colin-Belgrand, M., Dambrine, E., Martin, F., $1998 .{ }^{15} \mathrm{~N}$ partitioning and production of ${ }^{15} \mathrm{~N}$-labelled litter in beech trees following $\left[{ }^{15} \mathrm{~N}\right]$ urea spray. Annales des Sciences Forestières 55, 375-383.

Zeller, B., Colin-Belgrand, M., Dambrine, E., Martin, F., Bottner, P., 2000. Decomposition of ${ }^{15} \mathrm{~N}$-labelled beech litter and fate of nitrogen derived from litter in a beech forest. Oecologia 123, 550-559.

Zeller, B., Colin-Belgrand, M., Dambrine, E., Martin, F. 2001. Fate of nitrogen released from ${ }^{15}$ N-labelled litter in European beech forests. Tree Physiology 21, 153-162. 


\section{Appendix}

List of the taxa identified at Leinefelde and Sorø with indication of their size range and their feeding preferences

\begin{tabular}{|c|c|c|c|c|c|}
\hline \multirow[t]{2}{*}{ Taxa } & \multirow[t]{2}{*}{ Size } & \multirow[t]{2}{*}{ Feeding preferences } & \multirow[t]{2}{*}{ Abbreviation } & \multicolumn{2}{|c|}{ Identification } \\
\hline & & & & Leinefelde & Sorø \\
\hline Enchytraeidae & Medium & Saprophagous & Enchy sapro & + & + \\
\hline Lumbricidae & Large & Saprophagous & Lumbr sapro & + & + \\
\hline \multicolumn{6}{|l|}{ Chilopoda } \\
\hline Geophilomorpha & Large & Predators & Geophil pred & + & + \\
\hline Lithobiomorpha & Large & Predators & Litho pred & + & - \\
\hline \multicolumn{6}{|l|}{ Diplopoda } \\
\hline Glomeridae & Large & Saprophagous & Glom sapro & + & + \\
\hline Julidae & Large & Saprophagous & Jul sapro & + & + \\
\hline \multicolumn{6}{|l|}{ Oribatida } \\
\hline Phthiracaroidea & Medium & Saprophagous & Phthi sapro & + & + \\
\hline Nothroidea & Small & Saprophagous & Nothr sapro & + & + \\
\hline Belboidea & Small & Saprophagous & Belb sapro & + & + \\
\hline Eniochthonius & Small & Saprophagous & Enio sapro & + & + \\
\hline Achipteria & Small & Saprophagous & Achip sapro & + & + \\
\hline \multicolumn{6}{|l|}{ Gamasida } \\
\hline Trachytes & Small & Predators & Trac pred & + & + \\
\hline Parasitidae & Small & Predators & Para pred & + & + \\
\hline Uropodidae & Small & Fungivorous & Urop fungi & + & + \\
\hline Eupopodidae & Small & Fungivorous & Eupo fungi & + & + \\
\hline Araneae & Large & Predators & Aran pred & + & + \\
\hline Pseudoscorpionida & Medium & Predators & Pscorp pred & + & + \\
\hline Isopoda & Large & Saprophagous & Isop sapro & + & + \\
\hline \multicolumn{6}{|l|}{ Collembola } \\
\hline Pogonognathellus & Large & $\begin{array}{c}\text { pollen, algae, fungi spora } \\
\text { herbifungivorous }\end{array}$ & Pogo herb & + & + \\
\hline Entomobrya & Large & $\begin{array}{c}\text { pollen, algae, fungi spora } \\
\text { herbifungivorous }\end{array}$ & Entomo herb & + & + \\
\hline Sminthurinus & Small & $\begin{array}{c}\text { pollen, algae, fungi spora } \\
\text { herbifungivorous }\end{array}$ & Smin $S$ herb & + & + \\
\hline Lepicocyrtus & Medium & $\begin{array}{l}\text { fungi hyphae, algae } \\
\text { herbifungivorous }\end{array}$ & Lepido M herb & + & + \\
\hline Folsomia & Small & Coprophagous & Folso $\mathrm{S}$ copro & + & + \\
\hline Isotomiella & Small & Coprophagous & Isoto $\mathrm{S}$ copro & + & - \\
\hline Pseudosinella & Small & Fungivorous & Psin $\mathrm{S}$ fungi & + & + \\
\hline Neanuridae & Small & $\begin{array}{l}\text { Phytophagous, litter } \\
\text { browser and sucker }\end{array}$ & Nea S phyto & + & + \\
\hline Onychiuridae & Small & Coprophagous & Ony S copro & + & - \\
\hline
\end{tabular}

